\title{
Is hypoxia a stressor to American bullfrog tadpoles? ${ }^{1}$
}

\author{
Patricia C. Teixeira2*, Fernanda M. França ${ }^{3}$, Guilherme C. da Rocha ${ }^{3}$, Antônio M. Antonucci³ \\ Claudia M. Ferreira ${ }^{3}$ and Maria José T. Ranzani-Paiva ${ }^{3}$
}

\begin{abstract}
Teixeira P.C., França F.M., Rocha G.C., Antonucci A.M., Ferreira C.M. \& Ranzani-Paiva M.J.T. 2014. Is hypoxia a stressor to American bullfrog tadpoles? Pesquisa Veterinária Brasileira 34(4):369-373. Centro de Aquicultura, Universidade Estadual Paulista, Via de Acesso Prof. Paulo Donato Castellane s/n, Jaboticabal, SP 14884-900, Brazil. E-mail: pa_co75@yahoo.com.br

The aim of this study was to evaluate alterations to the physiological profile of cortisol in pro-metamorphose phase tadpoles of Lithobates catesbeianus exposed to hypoxia stressor in a capture experiment and in a crowding experiment. The capture study was performed by the treatments: stress due to individual capture with a hand net, stress due to batch capture with a hand net and stress due to capture by emptying. Three simultaneous replicates was done witch 12 animals were sampled ( 6 normoxia - immediately blood collection) and 6 hypoxia - blood collection after 15 min of air exposition) in two collection times with 5 days by intervals. The crowding study was performed by the treatments 1 tadpole $\mathrm{L}^{-1}, 5$ tadpoles $\mathrm{L}^{-1}$ and 10 tadpoles $\mathrm{L}^{-1}$. Three simultaneous replicates was done witch 8 animals ( 4 normoxia and 4 hypoxia) were sampled in the zero moment (ZM) - blood collection before the experiment, 6 animals/treatment ( 3 normoxia and 3 hypoxia) to 4 and 8 days and 18 animals/treatment ( 9 normoxia and 9 hypoxia) to 12 days. The average values to plasmatic cortisol varying from 1.7 to $5.1 \mathrm{ng} \mathrm{mL}^{-1}$ (capture study) and 1.0 to $4.2 \mathrm{ng} \mathrm{mL}^{-1}$ (crowding study). It concludes that the biomarker tested (cortisol) showed no alterations front of the stressor used. Alternatively, a larger response pattern to these stimuli may have been expressed in another level of an unmeasured hormone (corticosterone). And the bullfrog has great ability to adapt to different management compared to other aquatic organisms, which demonstrates the plasticity of these animals.
\end{abstract}

INDEX TERMS: Frogculture, American bullfrog, Lithobates catesbeianus, tadpole, stress, cortisol.

RESUMO.- [A hipóxia é um estressor para girinos de rã-touro?] Avaliou-se o cortisol em girinos de rã-touro ( $\mathrm{Li}$ thobates catesbeianus), no estágio de pró-metamorfose ao mecanismo estressor de hipóxia juntamente com captura ( $1^{\circ}$ experimento) e adensamento ( $2^{\circ}$ experimento). 0 experimento de captura foi composto pelos tratamentos: Captura individual com puçá, Captura em massa com puçá e Captura por escoamento, com 3 réplicas simultâneas onde 12 organismos foram amostrados (6 normoxia - coleta imediata de sangue e 6 hipoxia - coleta de sangue após $15 \mathrm{~min}$

\footnotetext{
${ }^{1}$ Received on November 5, 2013.

Accepted for publication on March 10, 2014.

${ }^{2}$ Centro de Aquicultura (CA), Universidade Estadual Paulista (Unesp), Via de Acesso Prof. Paulo Donato Castellane s/n, Jaboticabal, SP 14884900, Brazil.*Corresponding author: pa_co75@yahoo.com.br

${ }^{3}$ Instituto de Pesca, Av. Francisco Matarazzo 455, São Paulo, SP 05001 900, Brazil.
}

de exposição ao ar) em 2 tempos de coleta com intervalo de 5 dias. 0 experimento de densidade foi composto pelos tratamentos: 1 girino $\mathrm{L}^{-1}, 5$ girinos $\mathrm{L}^{-1}$ e 10 girinos $\mathrm{L}^{-1}$, com 3 réplicas simultâneas onde 8 animais ( 4 normoxia e 4 hipoxia) foram amostrados no momento zero (MZ) - coleta de sangue anterior ao experimento, 6 animais/tratamento ( 3 normoxia e 3 hipoxia) para 4 e 8 dias e 18 animais/tratamento ( 9 normoxia e 9 hipoxia) para 12 dias. Os valores médios para o cortisol plasmático foram de 1,7 a $5,1 \mathrm{ng} \mathrm{mL}^{-1}$ (Experimento de Captura); e 1,0 a 4,2ng mL ${ }^{-1}$ (Experimento de Densidade). Conclui-se que o marcador biologico de estresse utilizado (cortisol) não foi alterado pelo agente extressor. Alternativamente a resposta a este estímulo pode ser expressa em outro nível hormonal (corticosterona). E a rã-touro apresenta ótima capacidade de se adaptar aos diferentes manejos se comparados a outros organismos aquáticos, o que demonstra a plasticidade destes animais. 
TERMOS DE INDEXAÇÃO: Ranicultura, American bullfrog, Lithobates catesbeianus, tadpole, estresse, cortisol.

\section{INTRODUCTION}

Many adult fishes, amphibians and reptiles increase their dependence upon aerial oxygen uptake as aquatic oxygen declines, and show a variety of cardiac and respiratory responses that facilitate this transition (Burggren \& Wood 1981, Burggren \& West 1982).

The great majority of studies on the effects of hypoxia on gas exchange processes in ectothermic vertebrates have been confined to responses to acute hypoxia. Respiratoryhomeostasis during acute hypoxic exposure is usually maintained by increases in the convective flow of air or water through gas exchange organs (Dejours 1981). Acute hypoxia is characterized by the remarkably selective redistribution of blood flow that ensures adequate oxygen supply to vital organs as regional blood flow increases in the brain, respiratory muscles, and liver but decreases in the gastroenteric tract, pancreas, spleen, skin, and limb bones. However, this disturbed blood flow distribution returns to the state of normoxia when the hypoxic state ends (Oka et al. 2007).

Compared with most birds and mammals, lower vertebrates (fishes, amphibians, and reptiles) are tolerant of variable oxygen availability (Bickler \& Buck 2007). When faced with hypoxia in the environment, anurans respond by increasing ventilation, heart rate and pulmocutaneous blood flow to maintain $\mathrm{O}_{2}$ delivery in face of the reduced oxygen availability (Kruhøffer et al. 1987, Wang et al. 1994, Gamperl et al. 1999, Wang et al. 1999). These cardio-respiratory adjustments are, at least in part, due to released vagal tone (Gamperl et al. 1999), but the adrenergic control is largely unknown. It is, nevertheless, well established that the sympathetic nervous system can exert significant cardio-respiratory and metabolic functions during stressful situations and that catecholamines affect cardiac function and vascular resistances in amphibians (Lillo 1979, Herman \& Sandoval 1983).

The aim of this study was to investigate the possible alterations in level of cortisol in American bullfrog tadpoles (Lithobates catesbeianus) exposed to hypoxia stressor.

\section{MATERIALS AND METHODS}

This study was composed by two experiments, a capture experiment and a crowding one using the hypoxia as a stressor in American bullfrog tadpoles (Lithobates catesbeianus) in the pro-metamorphosis phase.

In the capture experiment, the animals, acquired from the Frog Farming of Aquacultural Center of São Paulo State University (CAUNESP), Jaboticabal/SP, Brazil (mean weight of $9.05 \mathrm{~g}$ and mean length of $11.96 \mathrm{~cm}$ ) were transported to Experimental Frog Farming of Aquacultural Center of Agricultural Department of São Paulo State (PRDTAVP), Pindamonhangaba/SP, Brazil, and acclimated for 7 days. They were randomly distributed in polyethylene tanks (500 litters), at a density of 1 tadpole $\mathrm{L}^{-1}$ witch in the field were conditioned using an agricultural oven where the surface was covered with polyethylene plastic and the sides with nylon screen. The treatments performed were: individual capture with a hand net (Treatment 1), batch capture with a hand net
(Treatment 2) and capture by emptying (Treatment 3), the traditional handling used in Brazil frog farming. Each treatment was carried out in simultaneous triplicate in a random order. The samples were obtained on two sets of collections with an interval of 5 days between them witch 12 individuals were used ( 6 normoxia blood collected immediately, and 6 hypoxia - blood collected after 15 min air exposition), totalling 72 animals sampled.

In the crowding experiment, the animals, acquired from a particular propriety (mean weight $10.32 \mathrm{~g}$ and mean length $11.18 \mathrm{~cm}$ ), were transported to Reference Laboratory Unit for Pathology of Aquatic Organisms at the Fisheries Institute in São Paulo/SP, Brazil, and acclimated for 7 days. They were randomly distributed in aquariums in the laboratory, 20 tadpoles per unit witch the treatments performed were 1 tadpole $\mathrm{L}^{-1}$ (Treatment 1 - control group), 5 tadpole $\mathrm{L}^{-1}$ (Treatment 2) and 10 tadpole $\mathrm{L}^{-1}$ (Treatment 3), with 20, 4 and 2 litters of water respectively. Each treatment was carried out in simultaneous triplicate in a random order. The samples were obtained at ZM (zero moment - blood collected before the experiment), 4, 8 and 12 days. For the ZM, 8 animals were sampled ( 4 normoxia and 4 hypoxia), for the 4 and 8 days, 6 animals/treatment were collected ( 3 normoxia and 3 hypoxia) and for the final collection, 18 animals/treatment were sampled ( 9 normoxia and 9 hypoxia), totalling 98 animals sampled. The water levels were readjusted each time tadpoles were removed from the aquariums so that the density of the remaining animals was not altered.

Time to hypoxia was determined through preliminary tests because according to Bickler \& Buck (2007) extended periods of hypoxia probably involve gradual changes in homeostasis resulting in injury. The animals under normoxia condition were removed from the tanks/aquariums, placed in plastic boxes filled with water and immediately taken for blood collection. The animals under hypoxia conditions were removed from tanks/aquariums, placed in humid plastic boxes where they were exposed to air for 15 minutes, and then taken for blood collection.

The animals were fed commercial concentrate containing 45 $\%$ crude protein, $6 \%$ crude fibber and $9 \%$ ether extract, once per day in a ratio of $1 \%$ of live weight.

In the field, the ambient temperature, relative humidity of the air and physical-chemical parameters of the water (temperature, electrical conductivity, $\mathrm{pH}$, dissolved oxygen) were monitored daily. Total ammonia and nitrite were measured weekly. The water of each tank was continuous flow system. In the laboratory, only the physic-chemical parameters of water (temperature, electric conductivity, $\mathrm{pH}$, dissolved oxygen, ammonia, and nitrite) were monitored daily. The hardness, alkalinity, and total ammonia were monitored every three days. The photoperiod was held constant at 12:12. The mortality was monitored daily in both experiments.

For physiological analyses, an aliquot of blood was obtained from the rupture of the caudal vessel with the aid of disposable needles and heparinized tips, after the application of Lidocaine as a local anaesthetic. In accordance with the circadian rhythm of the animals, blood collections took place in the morning hours (Herman 1992). The animals were subsequently anaesthesiated with benzocaine (1:10) and sacrificed. Blood samples were centrifuged at $1006 \mathrm{x} g$ for 10 minutes to obtain plasma witch was frozen on $-80^{\circ} \mathrm{C}$ freezer to posterior cortisol analysis with ELISA (Active Cortisol EIA DSL10 - Diagnostic System Labs USA).

A descriptive analysis of the variables was done to verify the differences between results of cortisol data among the different treatments. The normality was verified using the D'Agostino-Pearson test, and the homogeneity of variances was verified using the Bartlett test. In the capture experiment a two-way analysis of variance was conducted (both factors fixed), followed by Tukey test. In the crowding experiment, because the small number of 
observations and the not normal samples, the treatments were compared using the Kruskal-Wallis non-parametric test followed by the Student-Newman-Keuls test. Statistical tests were performed in the BioEstat 4.0 and Minitab 15, considering significant when $\mathrm{p} \leq 0.05$ (Zar 1999).

\section{RESULTS AND DISCUSSION}

The physic-chemical water parameters results, in both experiments, remained within the standards required to conduct tests with amphibians and were considered good using the standards for farming practices of these aquatic organisms according to Culley Jr (1991). No mortality was registered.

The mean plasma cortisol levels obtained during the capture experiment ranged from 1.7 to $5.1 \mathrm{ng} \mathrm{mL}^{-1}$ (Table 1); in the crowding ranged from 1.0 to $4.2 \mathrm{ng} \mathrm{mL}^{-1}$ (Table 2).

Some studies report oxygen availability on circulating catecholamines in amphibians (Boutilier \& Lantz 1989, Talbot \& Stiffler 1991, Kruhøffer et al. 1987, Gamperl et al. 1999, Andersen et al. 2001). Plasma catecholamine concentrations increase during hypoxia associated with acidosis in Xenopus and Ambystoma (Boutilier \& Lantz 1989, Talbot \& Stiffler 1991). Another study report arterial blood gases and plasma catecholamine levels during hypoxia in the toad Bufo marinus (Kruhøffer et al. 1987, Gamperl et al. 1999, Andersen et al. 2001).

Catecholamines are the first hormones released after exposure to hypoxia, with the highest levels occurring about 30 seconds after the perception of the stressor. Then, a simultaneous increase of cortisol levels occurs, with the highest concentrations of the hormone being detected 30 minutes after the disturbance in sparid red porgy (Rotllant \& Tort 1997). Oncorhynchus mykiss submitted to air exposure by $30 \mathrm{sec}$, the cortisol level show to be high 30 min after the proceeding in manipulated fishes than no manipulated fishes (Sloman et al. 2001). Air exposure pro-

Table 1. Mean values of plasma cortisol (ng mL-1) of $L$. catesbeianus tadpoles exposed to hypoxia in the different collections on the capture experiment

\begin{tabular}{|c|c|c|c|c|c|c|}
\hline \multirow[t]{2}{*}{ Period } & \multicolumn{2}{|c|}{$\begin{array}{c}\mathrm{T} 1 \\
\text { Individual capture }\end{array}$} & \multicolumn{2}{|c|}{$\begin{array}{c}\mathrm{T} 2 \\
\text { Batch capture }\end{array}$} & \multicolumn{2}{|c|}{$\begin{array}{c}\mathrm{T} 3 \\
\text { Capture by emptying }\end{array}$} \\
\hline & $(\mathrm{N})$ & $(\mathrm{H})$ & $(\mathrm{N})$ & $(\mathrm{H})$ & $(\mathrm{N})$ & (H) \\
\hline $1 \mathrm{st}$ & 1.7 & 3.0 & 3.2 & 3.8 & 2.7 & 2.6 \\
\hline 2nd & 2.3 & 3.6 & 5.1 & 2.5 & 3.1 & 2.1 \\
\hline
\end{tabular}

(N) Normoxia $=$ immediate blood collection, $(\mathrm{H})$ hypoxia $=$ blood collected after 15 minutes of air exposure.

Table 2. Median values of plasma cortisol (ng mL-1) of Lithobates catesbeianus tadpoles exposed to hypoxia in the different days of collection on the crowding experiment

\begin{tabular}{|c|c|c|c|c|c|c|}
\hline \multirow[t]{2}{*}{ Period (days) } & \multicolumn{2}{|c|}{$\begin{array}{c}\mathrm{T} 1 \\
1 \text { tadpole L-1 }\end{array}$} & \multicolumn{2}{|c|}{$\begin{array}{c}\mathrm{T} 2 \\
5 \text { tadpoles L-1 } \\
\end{array}$} & \multicolumn{2}{|c|}{$\begin{array}{c}\text { T3 } \\
10 \text { tadpoles L-1 }\end{array}$} \\
\hline & $(\mathrm{N})$ & $(\mathrm{H})$ & $(\mathrm{N})$ & $(\mathrm{H})$ & $(\mathrm{N})$ & $(\mathrm{H})$ \\
\hline 0 & 1.0 & 2.3 & 1.0 & 2.3 & 1.0 & 2.3 \\
\hline 4 & 1.8 & 2.8 & 1.0 & 3.9 & 1.6 & 4.2 \\
\hline 8 & 2.6 & 1.5 & 2.5 & 2.3 & 1.5 & 1.6 \\
\hline 12 & 2.5 & 28 & 27 & 1.5 & 2.2 & 21 \\
\hline
\end{tabular}

(N) Normoxia = immediate blood collection, $(\mathrm{H})$ hypoxia = blood collected after 15 minutes of air exposure. duced a 50 -fold increase in plasma cortisol concentrations and confinement for up to $24 \mathrm{~h}$ induced an initial increase in the plasma cortisol concentration up to eight times of that of controls in gilthead sea bream, S. aurata. (Arends et al. 1999). In other species, values can be higher, as in the golden perch, Macquaria ambigua (240 $\left.\mathrm{ng} \mathrm{mL}^{-1}\right)$ measured after $30 \mathrm{~min}$ of netting and confinement stress (Carragher \& Rees 1994).

Alterations resulting from the tested stressor stimuli, hypoxia, were not consistent with the classic stress response model; that is, an increase in glucocorticoid levels after exposure to a stressor stimulus.

According to Moberg (2000), Wada (2008), the mechanism related to the control of cortisol secretion is a complex process involving Adenocorticotropic Hormone (ACTH), which highlights the finding, that cortisol does not act alone. Specifically in the premetamorphosis and prometamorphosis stages, the synthesis of corticosteroids varies depending on the presented challenge (stressor stimulus) and the organism's life cycle (Belden et al. 2003, Crespi \& Denver 2004a, b, 2005). Plasmatic corticoids levels in the larval phase of most amphibian species show to be low during premetamorphosis, increasing during prometamorphosis and rise to a peak in the clímax of metamorphose in R. catesbeiana (Jaffe 1981, Krug et al. 1983, Kikuyama, Suzuki \& Iwamuro 1986); in X. laevis (Jolivet-Jaudet \& Leloup-Hatey 1984); in Ambystoma tigrinum (Carr \& Norris 1988) and in R. pipiens (Glennemeier \& Denver 2002a). The animals of both experiments showed low level of cortisol after stress stimulus, similar to basal one of some fishes, even in prometamorphosis phase.

According to Fritsche \& Burggren (1996) mild hypoxia is not necessarily detrimental to development, because compensating tissue level responses are evident.

Tadpoles, in fact, live entirely outside the water for considerable lengths of time (Wassersug \& Heyer 1983). In addition to having multiple sites for gas exchange and mastering the complexities of managing multiple exchange sites (lungs, gills, skin), the amphibious nature of most species means potentially altering gas exchange strategies on a minute-by-minute basis for the transition from air emersion to water immersion or vice versa (Wang et al. 2004). This 'plasticity' of tissues and even whole organs, which usually manifests itself only during the normal metamorphic process, apparently can be stimulated by environmental factors unrelated to development, such as hypoxic exposure, to produce morphological adjustments in respiratory structures which facilitate gas exchange under sub-optimum conditions (Burggren \& Mwalukoma 1983).

In tadpoles of ranid frogs, the gills and other buccopharyngeal surfaces account for no more than $10-40 \%$ of total $\mathrm{O}_{2}$ uptake (Burggren \& West 1982, West \& Burggren,1982, Burggren, Feder \& Pinder 1983). In R. catesbeiana tadpoles of developmental stages IV-XIX, about $60 \%$ of oxygen uptake occurs via the skin, while this falls to only $20 \%$ in the adult bullfrog (Burggren \& West 1982). This may result in part from the changing ventilation/perfusion relationships of the cutaneous and pulmonary vascular bed. The skin accounts for the majority of respiratory capillari- 
zation (Saint-Aubain 1982), is thin, and is the predominant route of $\mathrm{O}_{2}$ uptake in airbreathing tadpoles in normoxic water (Burggren \& West 1982, West \& Burggren 1982, Burggren, Feder \& Pinder 1983). Moreover, even though cutaneous gas exchange in amphibians is diffusion-limited along any given capillary (Piiper 1982), tadpoles can augment cutaneous exchange by perfusing additional capillaries or by increasing cutaneous capillarization and thinning the skin (Burggren \& Pinder 1982). Lungs are functional early in development witch tadpoles of all stages surface occasionally to breathe air and routinely have gas-filled lungs (Just et al. 1973, Ultsch det al. 1998). According to Burggren \& West (1982) and Feder (1983a) tadpoles of most anurans have well-developed lungs and breathe air regularly.

In addition, the partitioning of gas exchange in bullfrog tadpoles among these exchangers and between air and water depends on a number of factors, including body size, respiratory gas concentrations in the water, temperature, stage of development, rate of oxygen consumption $\left(\mathrm{VO}_{2}\right)$, and microhabitat (Noland \& Ultsch 1981, Burggren \& Doyle 1986, Burggren \& Infantino 1994, Ultsch et al. 1998). According to Feder $(1981,1982)$, the effects of mass, trophic state, time of day, feeding and stress were considered as factors influencing $\mathrm{VO}_{2}$.

So in fact no significant alterations were observed in the cortisol level front of the hypoxia in capture and crowding experiments. The tadpoles of both experiments certainly breathed air by lungs/skin when they were submitted to 15 minutes hypoxia so this mechanism did not represent stressful to elevate the cortisol compared to fishes submitted to the same stressor. Alternatively, a larger response pattern to these stimuli may have been expressed in another level of an unmeasured hormone (corticosterone). Additional studies are necessary to complement the information about stress physiology and its biomarkers for Lithobates catesbeianus, especially for intensive rearing systems.

Acknowledgments.- To FAPESP, for the financial support (Project 05/53070-0). To Fisheries Institute and Aquaculture Center (CAUNESP), for the assistance and academic support.

\section{REFERENCES}

Andersen J.B., Jensen F.B. \& Wang T. 2001. Effects of temperature and oxygen availability on circulating catecholamines in the toad Bufo marinus. Comp. Biochem. Physiol. A 129:473-486.

Belden L.K., Moore I.T., Mason R.T., Wingfield J.C. \& Blaustein A.R. 2003. Survival, the hormonal stress response and UV-B avoidance in Cascades Frog tadpoles (Rana catesbeiana) exposed to UV-B radiation. Funct. Ecol. 17:409-416.

Bickler P.E. \& Buck L.T. 2007. Hypoxia tolerance in reptiles, amphibians, and fishes: life with variable oxygen availability. Annu. Rev. Physiol. 69:145-170.

Boutilier R.G. \& Lantz C.J. 1989. The effects of forced and voluntary diving on plasma catecholamines and erythrocyte $\mathrm{pH}$ in the aquatic anuran, Xenopus laevis. Exp. Biology 48:83-88.

Burggren W.W. \& Wood S.C. 1981. Respiration and acid-base balance in the tiger salamander, Ambystoma tigrinum: Influence of temperature acclimation and metamorphosis. J. Comp. Physiol. 144:241-246.

Burggren W.W. \& Just J.J. 1992. Developmental changes in physiological systems, p.467-530. In: Feder M.E. \& Burggren W.W. (Eds), Environmental Physiology of the Amphibians. University of Chicago Press, Chicago.
Burggren W.W. \& Pinder A.W. 1982. Chronic hypoxia produces different hematological and respirator morphometric effects in larval vs. adult bullfrogs (Rana catesbeiana). Physiologist 25:249.

Burggren W.W. \& West N.H. 1982. Changing respiratory importance of gills, lungs and skin during metamorphosis in the bullfrog, Rana catesbeiana. Respir. Physiol. 47:151-164.

Burggren W.W., Feder M.E. \& Pinder A.W. 1983. Temperature and the balance between aerial and aquatic respiration in larvae of Rana berlandieri and Rana catesbeiana. Physiol. Zool. 56:263-273.

Burggren W.W. \& Mwalukoma A. 1983. Respiration during chronic hypoxia and hyperoxia in larval and adult bullfrogs (Rana catesbeiana). I. Morphological responses of lungs, skin and gills. J. Exp. Biol. 105:191-204.

Burggren W.W. 1984. Transition of respiratory processes during amphibian metamorphosis: from egg to adult, p.31-53. In: Seymour R.S. (Ed.), Respiration and Metabolism of Embryonic Vertebrates. Junk, Dordrecht.

Burggren W.W. \& Doyle M. 1986. Ontogeny of regulation of gill and lung ventilation in the bullfrog, Rana catesbeiana. Respir. Physiol. 66:279291.

Burggren W.W. \& Infantino Jr R.L. 1994. The respiratory transition from water to air breathing during amphibian metamorphosis. Am. Zool. 34:238-246

Carr J.A. \& Norris D.O. 1988. Interrenal activity during metamorphosis of the Tiger Salamander, Ambystoma tigrinum. Gen. Comp. Endocr. 71:6369.

Crespi E.J. \& Denver R.J. 2004a. Roles of corticotropin-releasing factor, neuropeptide-y, and corticosterone in the regulation food intake in Xenopus laevis. J. Neuroendocrinol. 16:279-288.

Crespi E.J. \& Denver R.J. 2004b. Ontogeny of corticotropin-releasing factor on locomotion and foraging in the western spadefoot toad, Spea hammondii. Horm. Behav. 46:399-410.

Crespi E.J. \& Denver R.J. 2005. Roles of stress hormones in food intake regulation in anuran amphibians throughout the life cycle. Comp. Biochem. Physiol. A 141:381-390.

Culley Jr D.D. 1991. Bullfrog culture, p.185-205. In: Neimann-Sorensen A., Tribe D.E. \& Nash C.E. (Eds), Production of Aquatic Animals: crustaceans, mollusks, amphibians and reptiles. Elsevier- World Animal Science C4, Amsterdam.

Dejours P. 1981. Principals of Comparative Respiratory Physiobgy. Elsevier/North Holland, New York. 265p.

Feder M.E. 1981. Effect of body size, trophic state, time of day, and experimental stress on oxygen consumption of anuran larvae: an experimental assessment and evaluation of the literature. Comp. Biochem. Phys. A 70:497-508.

Feder M.E. 1982. Effect of body size and developmental stage on oxygen consumption of anuran larvae: a reappraisal. J. Exp. Zool. 220:33-42.

Feder M.E. 1983. Responses to acute aquatic hypoxia in larvae of the frog Rana berlandieri. J. Exp. Biol. 104:79-95.

Feder M.E \& Wassersug R.J. 1984. Aerial versus aquatic oxygen consumption in larvae of the clawed frog, Xenopus laevis. J. Exp. Biol. 108:231245.

Fritsche R. \& Burggren W.W. 1996. Development of cardiovascular responses to hypoxia in larvae of the frog Xenopus laevis. Am. J. Physiol. 271 (Regulatory Integrative Comp. Physiol. 40):R912-R917.

Gamperl A.K., Milsom W.K., Farrell A.P. \& Wang T. 1999. Cardiorespiratory responses of the toad (Bufo marinus) to hypoxia at two different temperatures. J. Exp. Biol. 202:3647-3658.

Glennemeier K.A. \& Denver R.J. 2002a. Small changes in whole-body corticosterone content affect larval Rana pipiens fitness components. Gen. Comp. Endocrinol. 127:16-25.

Herman C.A. \& Sandoval E.J. 1983. Catecholamine effects on blood pressure and heart rate in the American bullfrog, Rana catesbeiana. Gen. Comp. Endocrinol. 52:142-148.

Jaffe R.C. 1981. Plasma concentration of corticosterone during Rana catesbeiana tadpole metamorphosis. Gen. Comp. Endocrinol. 44:314-318.

Jolivet-Jaudet G. \& Leloup-Hatey J. 1984. Variations in aldosterone and 
corticosterone plasma levels during metamorphosis in Xenopus laevis tadpoles. Gen. Comp. Endocrinol. 56:59-65.

Just J.J., Gatz R.N. \& Crawford E.C. 1973. Changes in respiratory function during metamorphosis in the bullfrog, Rana catesbeiana. Respir. Physiol. $17: 276-282$

Kikuyama S., Suzuki M.R. \& Iwamuro S. 1986. Elevation of plasma aldosterone levels of bullfrog tadpoles at metamorphic climax. Gen. Comp. Endocrinol. 63:186-190.

Krug E.C., Honn K.V., Battista J. \& Nicoll C.S. 1983. Corticosteroids in serum of Rana catesbeiana during development and metamorphosis. Gen. Comp. Endocrinol. 52:232-241.

Kruhøffer M., Glass M.L., Abe A.S. \& Johansen K. 1987. Control of breathing in an amphibian Bufo paracnemis: effects of temperature and hypoxia. Respir. Physiol. 69:267-275.

Lillo R.S. 1979. Autonomic cardiovascular control during submergence and emergence in bullfrogs. Am. J. Physiol. 237:R210-R216.

Moberg G.P. 2000. Biological response to stress: implications for Animal Welfare, p.1-21. In: Moberg G.P. \& Mench J.A. (Eds), The Biology of Animal Stress: basic principles and implications for animal welfare. CABI Publishing, CAB International, Oxon.

Noland R. \& Ultsch G.R. 1981. The roles of temperature and dissolved oxygen in microhabitat selection by the tadpoles of a frog (Rana pipiens) and a toad (Bufo terrestris). Copeia 1981:645-652.

Oka T., Itoi T. \& Hamaoka K. 2007. Impaired transient elevation of blood hemoglobin in response to acute hypoxia in neonates with asplenia. Pediatrics International 49:898-902.

Piiper J. 1982. A model for evaluating diffusion limitation in gas-exchange organs of vertebrates, p.49-64. In: Taylor R., Johansen K. \& Bolis L. (Eds), A Companion to Animal Physiology. Cambridge University Press, Cambridge.
Rotllan J. \& Tort L. 1997. Cortisol and glucose responses after acute stress by net handling in the sparid red porgy previously subjected to crowding stress. J. Fish Biol. 51:21-28.

Saint-Aubain M.L. 1982. The morphology of amphibian skin before and after metamorphosis. Zoomorphology 100:55-63.

Sloman K.A., Metcalfe N.B., Taylor A.C. \& Gilmour K.M. 2001. Plasma cortisol concentrations before and after social stress in rainbow trout and brown trout. Physiol. Biochem. Zool. 74:383-389.

Talbot C.R. \& Stiffler D.F. 1991. Effects of hypoxia on acid-base balance, blood gases, catecholamines, and cutaneous ion exchange in the larval tiger salamander (Ambystoma tigrinum). J. Exp. Zool. 257:299-305.

Ultsch G.R., Bradford D.F. \& Freda J. 1998. Physiology: coping with the environment. In: McDiarmid R.W. \& Altig R. (Eds), Tadpoles: the Biology of anuran larvae. University of Chicago Press, Chicago. p.189-214.

Wada H. 2008. Glucocorticoids: mediators of vertebrate ontogenetic transitions. Gen. Comp. Endocrinol. 156(3):441-453.

Wang T., Branco L.G.S. \& Glass M.L. 1994. Ventilatory responses to hypoxia in the toad Bufo paracnemis before and after a decrease in haemoglobin oxygen-carrying capacity. J. Exp. Biol. 186:1-8.

Wang T., Hedrick M.S., Ihmied Y.M. \& Taylor E.W. 1999. Control and interaction of the cardiovascular and respiratory systems in anuran amphibians. Comp. Biochem. Physiol. A 124:395-408.

Wassersug R.J. \& Heyer W.R. 1983. Morphological correlates of sub-aerial existence in leptodactylid tadpoles associated with flowing water. Can. J. Zool. 61: 761-769.

West N.H. \& Burggren W.W. 1982. Gill and lung ventilatory responses to steady-state aquatic hypoxia and hyperoxia in the bullfrog tadpole (Rana cateibeiana). Respir. Physiol. 47:165-176. 